\title{
Fine Structure of the Parathyroid and Ultimobranchial Glands of the Snake, Elaphe quadrivirgata
}

\author{
By \\ Kishiko YOSHIDA-TERASAWA ${ }^{1)}$, Daisuke HAYAKAWA ${ }^{1)}$, Huayue CHEN ${ }^{1)}$, \\ Shoichi EMURA ${ }^{2)}$, Akira TAMADA ${ }^{2)}$, Toshihiko OKUMURA ${ }^{\text {3) }}$ and \\ Shizuko SHOUMURA ${ }^{1)}$
${ }^{1}$ Department of Anatomy, ${ }^{3}$ Laboratory of Electron Microscope, Gifu University School of Medicine, 40 Tsukasa- machi, Gifu 500-8705, Japan \\ ${ }^{2}$ College of Medical Sciences, Gifu University, 70-1, Kitano-machi, Gifu 500-8807, Japan
}

- Received for Publication, June 30, 1998 -

\begin{abstract}
Key Words: Parathyroid gland, Ultimobranchial gland, Snake, Electron microscope
Summary: The ultrastructure of the parathyroid gland and ultimobranchial gland of the snake, Elaphe quadrivirgata, was studied.

The parenchyma of the parathyroid gland was consisted of chief cells arranged in cords. Oxyphil cells and waterclear cells were not recognized. The chief cells contained irregular shaped nucleus, moderately-developed mitochondria, granular endoplasmic reticulum and Golgi complexes. A few secretory granules of 100-300 nm in diameter distributed in the cytoplasm. Small aggregations of glycogen particles and lipid droplets were dispersed widely in the cytoplasm.

The ultimobranchial glands consisted of follicles and interfollicular aggregates of C-cells. Follicles were invaginated and composed of $\mathbf{C}$-cells, goblet cells and ciliated cells. C-cells were located in the basal position of the follicle and possessed variety of secretory granules of $100-300 \mathrm{~nm}$ in diameter in the basal region of the cell. C-cells presented various secretory cycles. Goblet cells projected microvilli into follicular lumen. At the apical region the goblet cells had large granules of 300-1,200 nm in diameter. Ciliated cells projected cilia intermixed with micovilli from the apical surface of the cell into the follicular lumen.
\end{abstract}

Parathyroid hormone (PTH), ultimobranchial gland hormone (calcitonin) and vitamin $\mathrm{D}$ are known as major calcium regulating hormone. PTH elevates serum calcium level, whereas calcitonin lowers antagonistically. It is mentioned when the ultimobranchial body became active, the parathyroid glands exhibited reduced activity (Srivastav and Rani, 1992; Srivastav et al., 1994).

The parathyroid glands are recognized in all vertebrates higher than fishes. In mammals C-cells are called parafollicular cells in the thyroid. In birds, reptiles, amphibian and fish C-cells form the independent organ, ultimobranchial gland.

The ultrastructure of the reptile parathyroid gland has been studied in turtles (Clark and Khairallah, 1972; Chin, 1974; Grandi, 1982), iguanas (Anderson and Capen, 1976), Japanese lizards (Isono et al., 1979) and geckos (Isono et al., 1986). The ultrastructure of the reptile ultimoranchial glands has been studied in turtles (Khairallah and Clark, 1971) and iguanas (Anderson and Capen,
1976). As there have been a few detailed papers on the ultrastructure of Elaphe quadrivirgata parathyroid glands and ultimobranchial glands, we observed these two glands of Elaphe quadrivirgata with electron microscopy.

The snake, Elaphe quadrivirgata (class Reptilia, order Squamata, suborder Ophidia) is the Japanese proper species that lives in Hokkaido, Honshu, Shikoku, Kyushu, Kunashiri Islands, Izu Islands and Osumi Islands (Matsui, 1987).

\section{Materials and Methods}

Twenty snakes of both sexes weighing $95-440 \mathrm{~g}$ were used. The snakes were collected from spring to autumn. The caudal parathyroid glands and ultimobranchial glands were excised under ether anesthesia. Both glands were fixed with Millonig's fixative and dehydrated through ascending concentrations of acetone. The specimens were embedded 
in Epon 812. Thin sections were cut on a PORTERBLUM MT-1 ultramicrotome, stained with uranyl acetate and lead salts, and examined with a Hitachi $\mathrm{H}-700 \mathrm{H}$ or Hitachi $\mathrm{H}-800$ electron microscope. For light microscopy 1-2 $\mu \mathrm{m}$ sections were cut and stained with $0.1 \%$ Azur II.

\section{Observations}

\section{Parathyroid gland}

Elaphe quadrivirgata possessed two pairs of parathyroid glands, the rostral and caudal glands. The parathyroid glands existed along the carotid artery. The caudal parathyroid glands were situated dorsal surface of the thymus (Fig. 1). The parathyroid glands were fusiform measuring $0.3-0.4 \mathrm{~mm}$ in short diameter and $0.4-1.2 \mathrm{~mm}$ in long diameter. Connective tissue capsule enclosed the parathyroid gland and divided the gland into the cell cords (Fig. 1).

The parenchyma consisted of chief cells alone. Oxyphil cells and water-clear cells were absent. The chief cells were round, spindle or polygonal in shape and arranged in cell cords (Figs. 2, 3).

The nucleus was irregular in shape (Fig. 3). Plasma membranes of adjacent chief cells pursued a straight course except for occasional interdigitations (Figs. 4, 5). Opposing plasma membranes were connected mainly by intermediate junctions (Fig. 5).

Mitochondria and granular endoplasmic reticulum were scattered throughout the cytoplasm (Fig. 5). Golgi complex was moderatelydeveloped (Fig. 6).

The chief cells had a few secretory granules containing homogeneously dense materials 100 $300 \mathrm{~nm}$ in diameter. Most secretory granules occured singly (Fig. 5). They appeared near the plasma membrane or in the Golgi region. Occasional secretory granule attached to the plasma membrane (Fig. 6). Lysosomes were round or irregular in shape measuring $250-1,000 \mathrm{~nm}$. Some lysosomes contained the lipid droplets, dense granules or vacuoles (Fig. 4). Small aggregations of glycogen particles dispersed in the cytoplasm (Figs. 4, 5). Lipid droplets measuring $140-1,000 \mathrm{~nm}$ occured in the cytoplasm (Fig. 4).

\section{Ultimobranchial gland}

The ultimobranchial gland was located near the caudal parathyroid gland and was oval or spindle in shape measuring about $0.7 \mathrm{~mm}$ in length and 0.4 $\mathrm{mm}$ in width. The connective tissue capsule enveloped the ultimobranchial gland (Fig. 7). The ultimobranchial gland was composed of invaginated follicles and interfollicular cell aggregates (Fig. 7). Follicular lumen was filled with the moderately electron dense substance (Fig. 8). There were three types of cells in the follicle walls (Fig. 8).

\section{(1) C-cells}

The C-cells were found not only in the follicular walls but also in interfollicular connective tissues forming the cell aggregates (Figs. 8, 9, 10). In the follicle the C-cells occupied the basal position. The nucleus was irregular in shape with deep indentations. Mitochondria and granular endoplasmic reticulum distributed throughout the cytoplasm. Welldeveloped Golgi complex was seen near the nucleus (Fig. 11). Many secretory granules of $100-300 \mathrm{~nm}$ in diameter of various electron densities were recognized near the basal region of the cell. Number and density of the secretory granules varied from cell to cell. Secretory granules attached to the lateral and basal cell membranes were often observed (Fig. 10). Lysosomes $300-500 \mathrm{~nm}$ in diameter contained heterogeneously electron dense materials (Fig. 9).

\section{(2) Goblet cells}

The apical surface of the goblet cell was covered with numerous microvilli (Fig. 12). Mitochondria and granular endoplasmic reticulum were distributed throughout the cytoplasm. The goblet cell had a lot of large granules $300-1,200 \mathrm{~nm}$ in diameter at the apical region of the cell. The large granules contained moderate electron dense, flocculent materials and dense cores. Some of the large granules attached to the apical surface of the follicular lumen (Fig. 12). The follicular lumen was filled with moderately dense materials (Figs. 8, 12).

\section{(3) Ciliated cells}

Abundant cilia were observed at the luminar surface (Figs. 8, 13). Numerous mitochondria were observed just beneath the basal bodies of the cilia (Fig. 13). Microvilli intermixed among cilia (Fig. 13).

\section{Discussion}

\section{Parathyroid gland}

As to the parathyroid function of reptile, experimental studies have been reported mainly through parathyroidectomy (Sidky, 1966; Oguro, 1970; Singh and Kar, 1979). Parathyroidectomized freshwater turtles do not show any particular changes (Clark, 1965), whereas parathyroidectomized lizards die of hypocalcemia and tetany (Sidky, 1966; Clark et al., 1969). Though the parathyroidectomized 
Elaphe quadrivirgata and another species of snakes show the decrease in serum calcium, only few animals showed tetanic convulsions (Oguro, 1970; Singh and Kar, 1979).

The parenchyma of the parathyroid gland of Elaphe quadrivirgata consists of only one type chief cell same as Japanese lizard (Isono et al., 1979) and gecko (Isono et al., 1986). Oxyphil cells are observed in the mammalian parathyroid gland such as, human, ape, horse, cow and bat (Shoumura et al., 1993). In reptile, Clark and Khairallah (1972) has reported the existence of oxyphil cells in the fresh-water turtles. In the present study no oxyphil cells are observed in Elaphe quadrivirgata parathyroid glands. Emura et al. $(1990,1992)$ have reported the water-clear cells which contain numerous vacuoles in the parathyroid chief cells of the golden hamster and rabbit. Anderson and Capen (1976) have observed the stellate cells which are situated peripherally in the cell cords of iguanas. We recognized no water-clear cells and stellate cells in Elaphe quadrivirgata parathyroid gland.

The nucleus of the chief cell is smooth without indentations in mammals (Isono et al., 1982, 1990; Emura et al., 1984) and birds (Shoumura, 1974; Isono et al., 1978b), whereas in reptile (Isono et al., 1979, 1986) and amphibia (Isono et al., 1971, 1978a) the nucleus is irregular with deep indentations. There seems to be a tendency that lower vertebrates or aged animals have irregular nucleus in the parathyroid gland (Isono et al., 1977; Shoumura et al., 1993). In the present study the nucleus of the parathyroid chief cell shows deep indentations, though ages of Elaphe quadrivirgata used are unknown.

Lysosomes are larger than secretory granules and contain heterogeneously dense materials. The localization of acid phosphatase activity was demonstrated on the heterogeneously dense bodies in the mouse parathyroid gland (Hayashi et al., 1980). Lysosomes are supposed to have the function disposing secretory products of the cell in the same way of other endocrine organs.

Abundant glycogen particles are observed in human fetus and in hamster and rabbit in experimentally suppressed conditions (Shoumura et al., 1993). It is also mentioned the abundant lipid droplets is characteristic in the parathyroid gland of aged animal or animal in inactive condition (Shoumura et al., 1993).

Isono et al. have reported $(1979,1986)$ that the ultrastructural features of the parathyroid chief cell of gecko and Japanese lizard in spring and summer resemble each other and they are also similar to the active chief cells of other animal species. The chief cells of Elaphe quadrivirgata in the present study seem to be less active than those of the gecko and Japanese lizard. These observations are in agreement with the report on the function of the snake parathyroid gland (Oguro, 1970).

\section{Ultimobranchial gland}

It has been reported that snakes have one pair of the ultimobranchial glands and that the glands are located midway between the rostral and caudal pairs of the parathyroid glands (Singh and Kar, 1983; Padgaonkar et al., 1992). In the present study Elaphe quadrivirgata ultimobranchial glands are found near the caudal parathyroid glands.

In amphibia the ultimobranchial gland mainly consists of follicles (Robertson, 1971; Coleman and Phillips, 1972; Welsch and Schubert, 1975; Sasayama et al., 1990). In reptile and bird, the ultimobranchial gland consists of follicles and interfollicular cell aggregates (Stoeckel and Porte, 1967; Clark, 1971; Khairallah and Clark, 1971; Youshak and Capen, 1971; Anderson and Capen, 1976; Chan, 1978, 1982; Hodges, 1979; Singh and Kar, 1983; Ito et al., 1986; Boudbid et al. 1987; Padgaonkar et al., 1992; Eliam-Cisse et al., 1993). In reptiles the population of follicles to the cell aggregates is higher than that in birds (Boudbid et al., 1987). In the present study the follicles are dominant same as other reptiles.

The ultrastructural characteristics of C-cells of Elaphe quadrivirgata are similar to those of turtles (Khairallah and Clark, 1971) and iguanas (Anderson and Capen, 1976). Boudbid et al. (1987) have demonstrated that immunoreactive C-cells are found at the periphery close to the basal lamina in follicles and interfollicular cell masses in freshwater turtles.

As some of the secretory granules of C-cells are attached to the lateral or basal plasma membrane, it seems that the contents of the granules are to be discharged with exocytosis as same as turtles (Khairallah and Clark, 1971).

C-cells of various storage phases reflect different secretory cycles in Elaphe quadrivirgata ultimobranchial gland in the present study.

Goblet cells are seen in birds (Chan, 1978, 1982; Hodges, 1979), reptiles (Khairallah and Clark, 1971; Anderson and Capen, 1976; Singh and Kar, 1983) and amphibia (Coleman and Phillips, 1972). The large granules attach to the apical surface of the goblet cell suggesting the exocytosis. The electron density of large granules are similar to the density of the lumen contents. The ultimobranchial gland derived from the pharyngeal pouch. It seems that the goblet cells and the ciliated cells still retain the pharyngeal nature.

Ito et al. (1986) have suggested that cyst of the 
chicken ultimobranchial gland may partly play a role in the storage of excess or unneeded hormonal products. It is unlikely in Elaphe quadrivirgata that the follicular lumen contains the secretory material from the C-cells, because the C-cell occupy the basal position of the follicle.

\section{References}

1) Anderson MP and Capen CC. Ultrastructural evaluation of parathyroid and ultimobranchial glands in iguanas with experimental nutritional osteodystrophy. Gen Comp Endocrinol 1976; 30:209-222.

2) Boudbid H, Leger AF, Pidoux E, Volle GE, Taboulet J, Moukhtar MS and Treilhou-Lahille F. Localization of a salmon calcitonin-like molecule in one type of ultimobranchial cells in the freshwater turtle Pseudemys scripta. Gen Comp Endocrinol 1987; 65:415-422.

3) Chan AS. Ultrastructure of the ultimobranchial follicles of the laying chicken. Cell Tissue Res 1978; 195:309-316.

4) Chan AS. Ultrastructure of the ultimobranchial gland of the laying chicken. Okajimas Folia Anat Jpn 1982; 59:87102.

5) Chin M. An electron microscopic study of the turtle parathyroid gland, with special reference to the seasonal changes. J Kyoto Prefec Univ Med 1974; 83:452-464. (in Japanese)

6) Clark NB. Experimental and histological studies of the parathyroid glands of fresh-water turtles. Gen Comp Endocrinol 1965; 5:297-312.

7) Clark NB. The ultimobranchial body of reptiles. J Exp Zool 1971; 178:115-124.

8) Clark NB and Khairallah LH. Ultrastructure of the parathyroid gland of fresh-water turtles. J Morphol 1972; 138:131-140.

9) Clark NB, Pang PK and Dix MW. Parathyroid glands and calcium and phosphate regulation in the lizard, Anolis carolinensis. Gen Comp Endocrinol 1969; 12:614-618.

10) Coleman $R$ and Phillips $A D$. Ultimobranchial gland ultrastructure of larval axolotls, Ambystoma mexicanum Shaw, with some observations on the newt Pleurodeles waltii Micahelles. Z Zellforsch 1972; 134:183-192.

11) Eliam-Cisse MC, Taboulet J, Bielakoff J, Lasmoles F, de Vernejoul MC and Treilhou-Lahille F. Influence of calcium, and vitamin D deficient diet on calcitonin gene expression in the ultimobranchial cells of the developing chicken. Gen Comp Endocrinol 1993; 89:195-205.

12) Emura $S$, Shoumura $S$ and Isono $H$. Age-related changes in the ultrastructure of the parathyroid gland of the golden hamster. Acta Sch Med Univ Gifu 1984; 32:636-662. (in Japanese)

13) Emura S, Shoumura S, Utsumi $M$, Yamahira $T$, Chen $H$, Arakawa $M$ and Isono $H$. Ultrastructure of a water-clear cell in the golden hamster parathyroid gland. $J$ Electron Microsc 1990; 39:172-177.

14) Emura $S$, Shoumura $S$ and Isono $H$. Ultrastrucure of the water-clear cell in the rabbit parathyroid gland. Arch Histol Cytol 1992; 55:159-166.

15) Grandi D. Sulla fine struttura della paratiroide di tartaruga di acqua dolce (Psaudemys scripta). Estratto da Acta BioMedia de [I'Ateneo Permerse] 1982; 53:219-235.

16) Hayashi $K$, Shoumura $S$ and Isono $H$. Experimental study of the mouse parathyroid gland. I. Quantitative electron microscopy after calcium administration and acid phospha- tase activity. J Clin Electron Microscopy 1980; 13:45-53.

17) Hodges $\mathrm{RD}$. The fine structure of the vesicular component of the ultimobranchial gland of the domestic fowl. Cell Tissue Res 1979; 197:113-135.

18) Isono $H$, Sakurai $S$, Fujii $H$ and Aoki S. Ultrastructural change in the parathyroid gland of the phosphate treated newt, Triturus pyrrhogaster (Boie). Arch histol jap 1971; 33:357-370.

19) Isono H, Miyake $K$, Shoumura $S$ and Barrnett RJ. Electron microscopic study on the postnatal development of the mouse parathyroid gland. Arch histol jap 1977; 40:367-380.

20) Isono $H$, Shoumura $S$, Miyake $K$, Ishizaki $N$ and Hayashi $K$. Effects of artificial hibernation on the ultrastructure of the parathyroid gland of the summer frog, Rana catesbiana. Okajimas Folia Anat Jpn 1978a; 55:41-56.

21) Isono $H$, Shoumura $S$ and Hayashi $K$. Ultrastructure of the parathyroid gland of the quail, Coturnix coturnix japonica. Okajimas Folia Anat Jpn 1978b; 55:241-254.

22) Isono $H$, Shoumura $S$, Ishizaki $N$, Hayashi $K$ and Yamahira T. Ultrastructure of the parathyroid gland of the Japanese lizard in the spring and summer season. J Morphol 1979; 161:145-156.

23) Isono $H$, Shoumura $S$, Ishizaki $N$, Emura $S$, Hayashi $K$, Iwasaki $Y$ and Kitamura Y. Effects of electrical stimulation of the vagus nerve on the ultrastructure of the rabbit parathyroid gland. Okajimas Folia Anat Jpn 1982; 58:453-466.

24) Isono $H$, Shoumura $S$, Ishizaki $N$, Emura $S$, Iwasaki $Y$ and Yamahira T. Electron microscopic study of the parathyroid gland of the gecko, Gekko Japonicus, in the spring and summer season. Okajimas Folia Anat Jpn 1986; 62:231240.

25) Isono I, Shoumura $S$ and Emura $S$. Ultrastructure of the parathyroid gland. Histol Histopathol 1990; 5:95-112.

26) Ito $M$, Kameda $Y$ and Tagawa $T$. An ultrastructural study of the cysts in chicken ultimobranchial glands, with special reference to C-cells. Cell Tissue Res 1986; 246:39-44.

27) Khairallah LH and Clark NB. Ultrastructure and histochemistry of the ultimobranchial body of fresh-water turtles. Z Zellforsch 1971; 113:311-321.

28) Matsui T. Japanese reptiles. Halliday TR, Adler K. eds. The encyclopedia of animals. Vol. 12 Amphibia and reptilia. Japanese ed. 158-163, Heibonsha, Tokyo, 1987. (in Japanese)

29) Oguro C. Parathyroid gland of the snake Elaphe quadrivirgata with special reference to parathyroidectomy. Gen Comp Endocrinol 1970; 15:313-319.

30) Padgaonkar AS, Kagwade MV and Warbhuwan A. Parathyroid and ultimobranchial glands of the estuarine snake, Cerberus rhynchops (Schneider). Gen Comp Endocrinol 1992; 86:395-397.

31) Robertson DR. Endocrinology of amphibian ultimobranchial glands. J Exp Zool 1971; 178:101-114.

32) Sasayama $Y$, Oguro $C$, Ogasawara $T$, Hirano $T$, Harumi $T$ and Wisessang $\mathrm{S}$. The crab-eating frog Rana cancrivora: Serum mineral concentrations and histology of the ultimobranchial gland and the parathyroid gland. Gen Comp Endocrinol 1990; 80:399-406.

33) Shoumura S. Electron microscopic study of the parathyroid glands of the pet birds. Fine structure of the parathyroid glands of the love birds and Australian love birds. Acta Sch Med Gifu 1974; 22:300-325. (in Japanese)

34) Shoumura $S$, Emura $S$ and Isono $H$. The parathyroid gland under normal and experimental conditions. Acta Anat 1993; 68:5-29.

35) Sidky YA. Effect of parathyroidectomy in lizards. Gen Comp Endocrinol 1966; 7:22-26.

36) Singh $R$ and Kar I. Effect of parathyroidectomy in the 
water snake, Natrix piscator. Gen Comp Endocrinol 1979; 39:411-413.

37) Singh $R$ and Kar I. Parathyroid and ultimobranchial glands of the sand boa, Eryx johnii Daudin. Gen Comp Endocrinol 1983; 51:66-70.

38) Srivastav AK and Rani L. Ultimobranchial body and parathyroid glands of the freshwater snake Natrix piscator in response to vitamin $D_{3}$ administration. J Exp Zool 1992; 262:255-262.

39) Srivastav AK, Rani L and Sasayama Y. Influence of prolactin administration on the ultimobranchial body and parathyroid glands of the freshwater snake, Natrix piscator.
Okajimas Folia Anat Jpn 1994; 71:59-66.

40) Stoeckel ME and Porte A. On the ultrastucture of the ultimobranchial body of the chicken. C R Acad Sc Paris 1967; 265:2051-2053.

41) Welsch $U$ and Schubert Ch. Observations on the fine structure, enzyme histochemistry, and innervation of parathyroid gland and ultimobranchial body of Chthonerpeton indistinctum (Gymnophiona, Amphibia). Cell Tissue Res 1975; 164:105-119.

42) Youshak MS and Capen CC. Ultrastructural evaluation of ultimobranchial glands from normal and osteopetrotic chickens. Gen Comp Endocrinol 1971; 16:430-442. 


\section{Explanation of Figures}

\section{Plate I}

Fig. 1. Diagrammatic representation showing the location of the parathyroid gland of the snake, Elaphe quadrivirgata. The caudal parathyroid glands (cPT) of Elaphe quadrivirgata lie near the thymus (TM). rPT: rostral parathyroid gland, H: heart, T: trachea, TR: thyroid gland.

Fig. 2. Azur II-stained semithin section of the parathyroid gland of Elaphe quadrivirgata. Connective tissue capsule (Cp) encloses the parathyroid gland that demonstrates cord like arrangement of the chief cells. Capillaries (C) penetrate into the cell cords from the capsule. Scale bar: $0.5 \mathrm{~mm}$.

Fig. 3. The parathyroid gland of Elaphe quadrivirgata. The parenchyma consists of a single cell type, chief cell. Chief cells are oval, spindle or polygonal in shape. The nuclei $(\mathrm{N})$ show irregular shape. C: capillary vessel. Scale bar: $1 \mu \mathrm{m}$.

Fig. 4. The parathyroid gland of Elaphe quadrivirgata. Lysosome (Ly) is irregular in shape and contain the lipid droplet. Glycogen particles (g) and lipid droplets (arrowhead) are seen in the cytoplasm. Scale bar: $1 \mu \mathrm{m}$. 

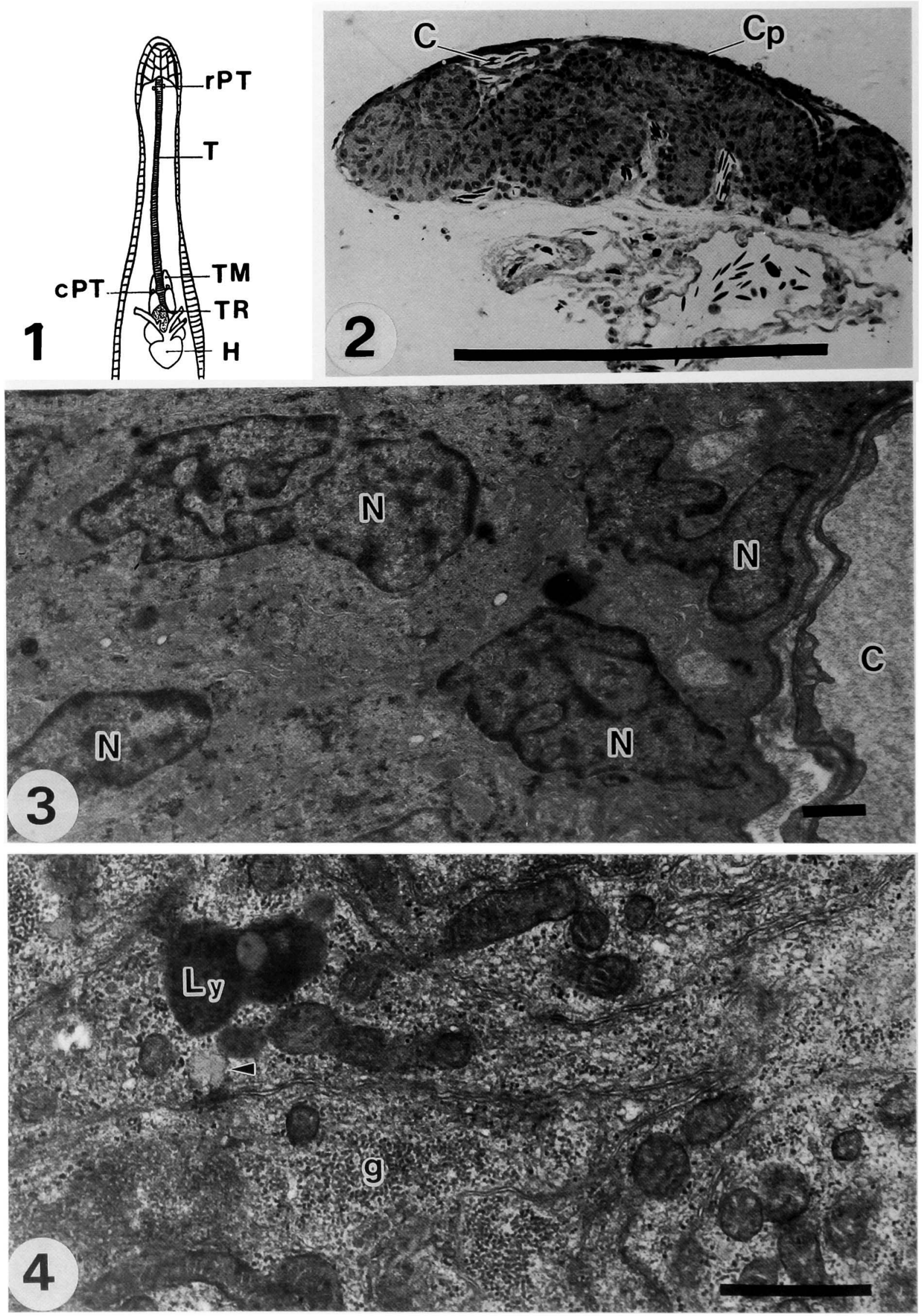


\section{Plate II}

Fig. 5. The parathyroid gland of Elaphe quadrivirgata. Plasma membranes pursue almost straight course with occasional interdigitations. Opposing plasma membranes are connected with intermediate junctions (arrowheads). Cisternae of the granular endoplasmic reticulum (ER) and mitochondria $(m)$ are scattered throughout the cytoplasm. Secretory granules (S) are observed near the Golgi complex (G) or close to the plasma membrane (S with *). N: nucleus, g: glycogen particles. Scale bar: $1 \mu \mathrm{m}$.

Fig. 6. The parathyroid gland of Elaphe quadrivirgata. Golgi complex (G) is relatively well developed. The Golgi cisternae form cup-like stacks and surround vesicles and vacuoles. A secretory granule (S) attaches to the plasma membrane. N: nucleus. Scale bar: $1 \mu \mathrm{m}$. 

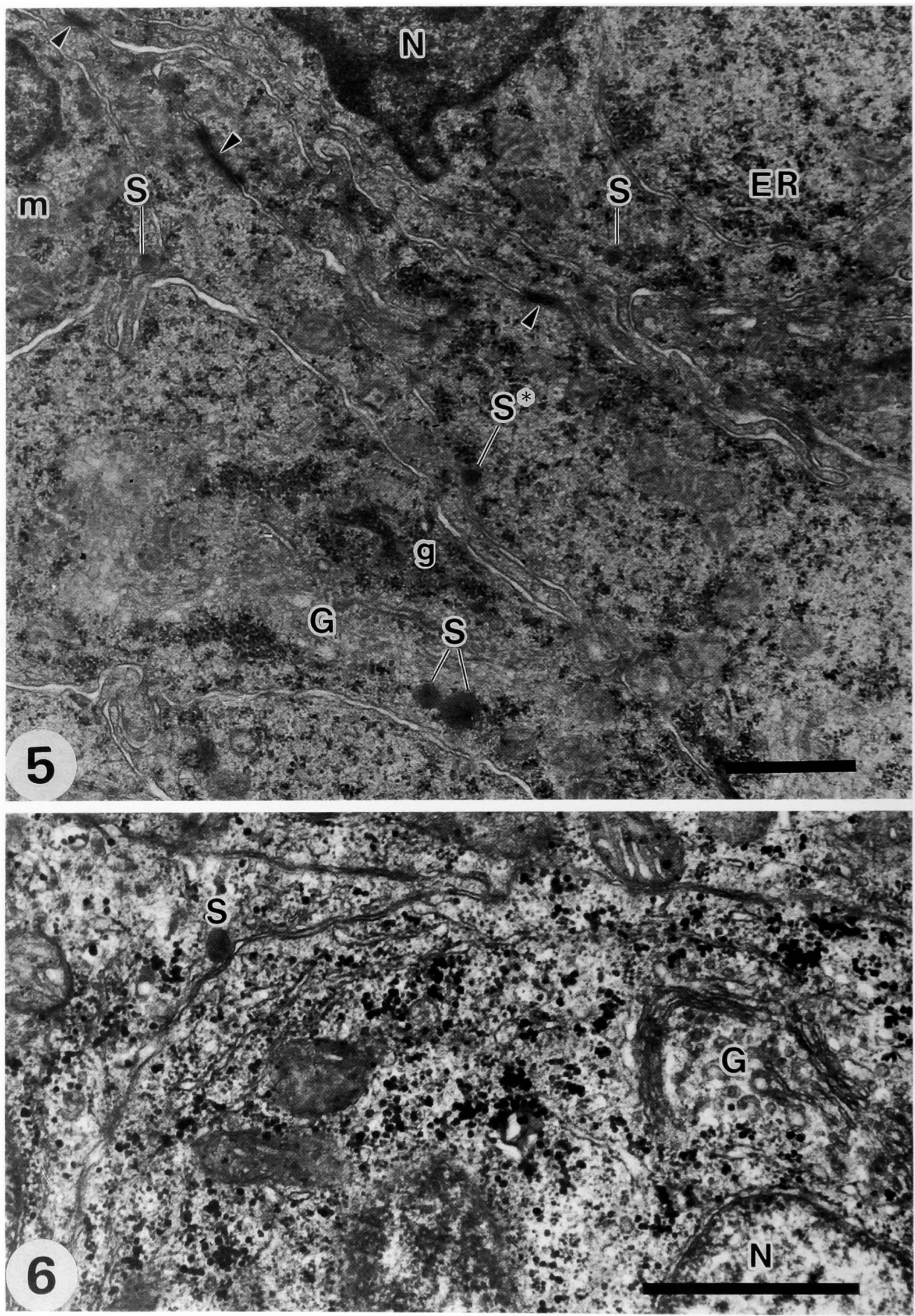
Plate III

Fig. 7. Azur II-stained semithin section of the ultimobranchial gland of Elaphe quadrivirgata. The ultimobranchial gland is composed of follicles (F) and interfollicular cell aggregates $\left(^{*}\right)$ and is enveloped with richly vascurized connective tissue capsule (arrows). Scale bar: $0.5 \mathrm{~mm}$.

Fig. 8. The ultimobranchial gland of Elaphe quadrivirgata. The follicles are composed of C-cells (C), goblet cells ( $\mathrm{gC}$ ) and ciliated cells (ciC). Follicular lumen (L) is filled with floccular materials of moderate electron density. The nuclei of the goblet cells show irregular profiles. Arrowhead: basal lamina. Scale bar: $1 \mu \mathrm{m}$. 

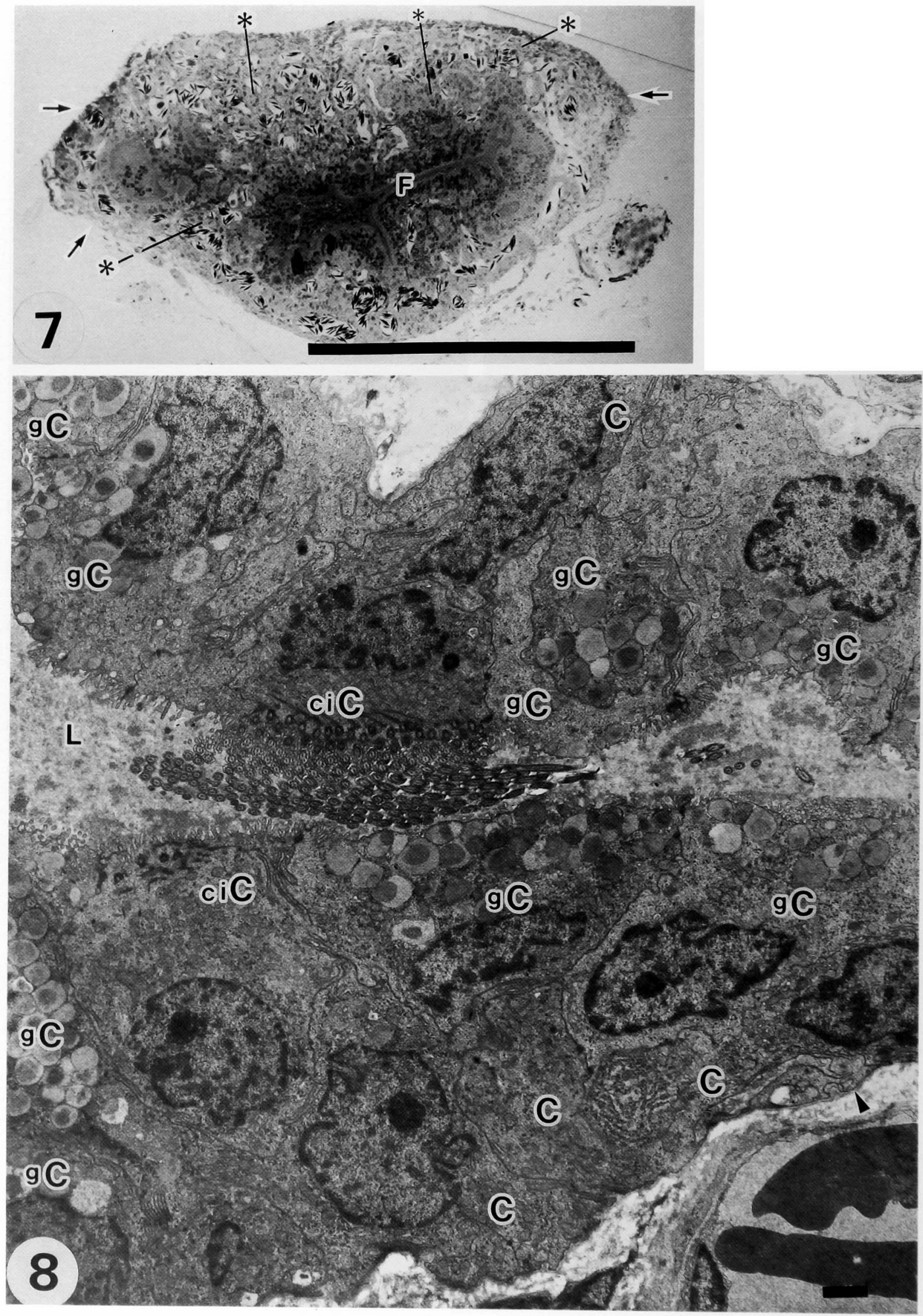


\section{Plate IV}

Fig. 9. The ultimobranchial gland of Elaphe quadrivirgata. C-cells form interfollicular cell aggregates. The nuclei are irregular in shape with deep indentation. Secretory granules (S) show various electron densities. Ly: lysosomes. Scale bar: $1 \mu \mathrm{m}$.

Fig. 10. The ultimobranchial gland of Elaphe quadrivirgata. Numerous secretory granules (S) of various electron densities are recognized at the basal region of the C-cells. Some granules situate close to the lateral cell membrane (arrow) or basal cell membrane (double arrow). N: nucleus, Arrowhead: basal lamina. Scale bar: $1 \mu \mathrm{m}$.

Fig. 11. The ultimobranchial gland of Elaphe quadrivirgata. The Golgi complex (G) of the C-cell is well developed. Stacked several sacs encircle numerous vesicles and secretory granules (arrows). N: nucleus. Scale bar: $1 \mu \mathrm{m}$.

Fig. 12. The ultimobranchial gland of Elaphe quadrivirgata. The goblet cells have many membrane-limited large granules. The electron density of some granules is similar to the content of the follicular lumen $(\mathrm{L})$. The large granules contain moderate electron dense and flocculent materials and dense cores. One of the granules $\left(^{*}\right)$ seems to discharge its contents into the follicular lumen. The apical surface of the goblet cell $(\mathrm{gC})$ is covered with microvilli $(\mathrm{mV})$. Scale bar: $1 \mu \mathrm{m}$.

Fig. 13. The ultimobranchial gland of Elaphe quadrivirgata. Ciliated cells have abundant cilia (Ci) intermixed with few microvilli $\left.{ }^{*}\right)$. Numerous mitochondria $(\mathrm{m})$ are observed just beneath the cilia. Scale bar: $1 \mu \mathrm{m}$. 


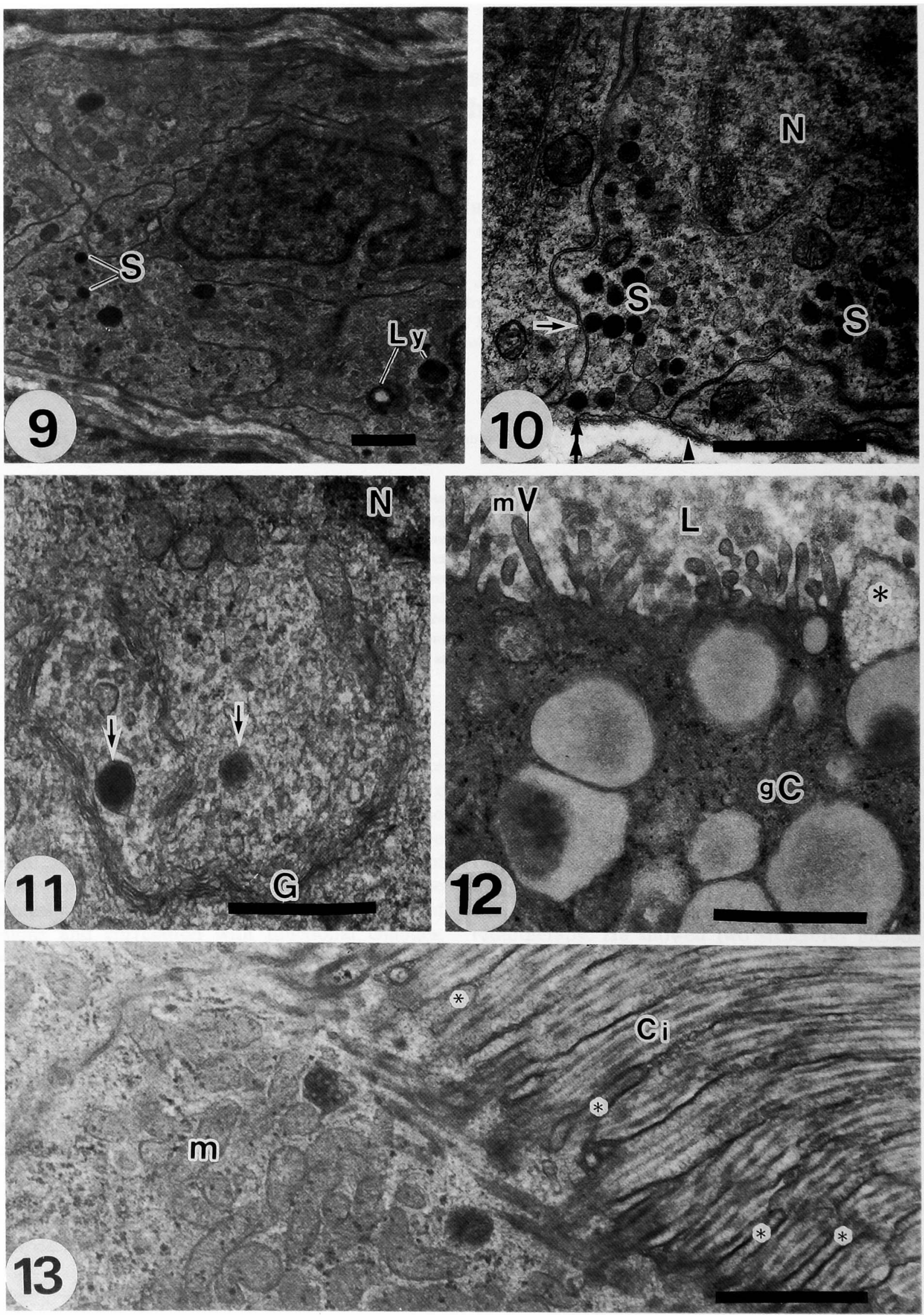

